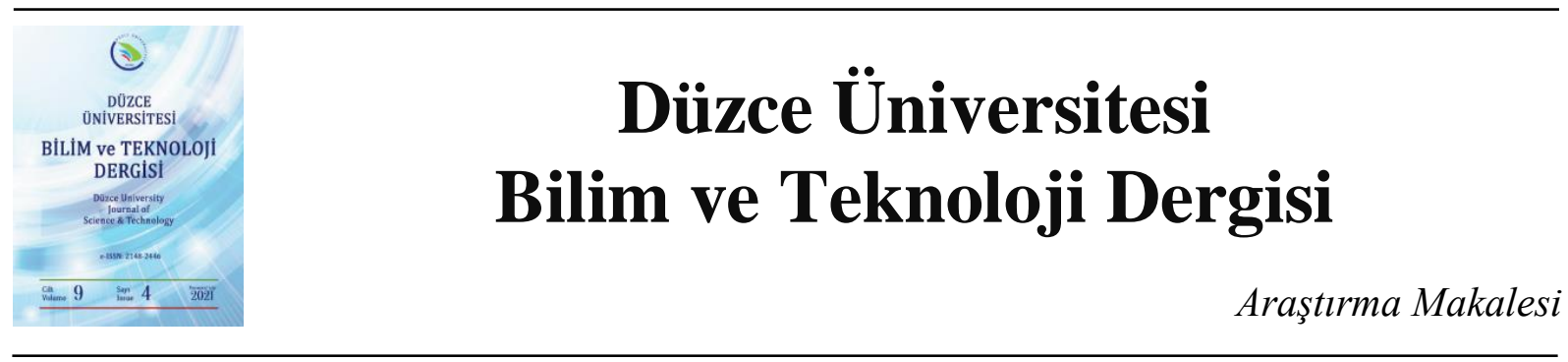

\section{Düşük Dolum Oranında İkili Karışımlarla Yüklü Üniform Olmayan Atımlı Isı Borusunun Deneysel İncelenmesi}

\author{
(iD) Burak MARKAL ${ }^{\mathrm{a}, *}$, (iD Ramazan VAROL ${ }^{\mathrm{b}}$ \\ ${ }^{a}$ Makine Mühendisliği Bölümü, Mühendislik ve Mimarlık Fakültesi, Recep Tayyip Erdoğan Üniversitesi, Rize, \\ TÜRKIYYE \\ ${ }^{b}$ Enerji Sistemleri Mühendisliği Bölümü, Mühendislik ve Mimarlık Fakültesi, Recep Tayyip Erdoğan \\ Üniversitesi, Rize, TÜRKIYYE \\ * Sorumlu yazarin e-posta adresi: burak.markal@erdogan.edu.tr \\ DOI: $10.29130 /$ dubited.879662
}

\begin{abstract}
$\underline{\mathrm{O} Z}$
$\mathrm{Bu}$ çalışmada, düşük bir dolum oranında ikili karışımlarla yüklü, üniform olmayan kanal profiline sahip düz plakalı kapalı döngülü atımlı bir ısı borusunun ısıl performansı ve akış davranışı deneysel olarak incelenmiştir. Deneyler kapsamında iş akışkanı olarak, etanol $(\mathrm{E})$ ve metanolün $(\mathrm{M})$ farklı hacim oranları $(\mathrm{E}: \mathrm{M}=1: 1,1: 2$ ve 2:1) için elde edilen ikili karışımları kullanılmıştır. Dolum oranı $\% 20$ olarak sabit tutulmuş olup; $0^{\circ}, 45^{\circ}$ ve $90^{\circ}$ olmak üzere üç farklı eğim açısında çalışılmıştır. Akış davranışı yüksek hızlı kamera ile elde edilen eş zamanlı görüntüler üzerinden irdelenmiştir (saniyede 1000 görüntü). Yapılan çalışma sonucunda; karışım oranının çalışmaya başlama performansı üzerinde önemli bir etkiye sahip olduğu; artan metanol oranı ile 1sıl performansın arttığı ve ısı borusunun, tüm karışım oranlarında, yer çekimi desteği olmadan da çalışabildiği belirlenmiştir. Isı transfer karakteristiklerinde artan eğim açısıyla iyileşme gözlemlenmiştir. Akış görüntüleri aracılığıyla, akış pasajları içerisindeki fiziksel olaylar tanımlanmıştır.
\end{abstract}

Anahtar Kelimeler: İkili Karışım, Isıl performans, Atımlı ısı borusu

\section{Experimental Investigation of a Non-Uniform Pulsating Heat Pipe Charged by Binary Mixtures at a Low Filling Ratio}

\begin{abstract}
In this study, thermal performance and flow behavior of flat-plate closed loop pulsating heat pipe having nonuniform channel profile and being charged by binary mixtures at a low filling ratio are experimentally investigated. In the experiments, binary mixtures of ethanol (E) and methanol $(\mathrm{M})$ obtained at different volume mixing ratio (E:M = 1:1, 1:2 and 2:1) are used as working fluid. The filling ratio is kept constant as 20\%; while it is studied three different inclination angles as $0^{\circ}, 45^{\circ}$ and $90^{\circ}$. Flow behavior is investigated via simultaneous images obtained by a high speed camera (1000 fps). It is concluded that the volume mixing ratio has a great importance on startup performance, the thermal performance increases with increasing methanol ratio, and the heat pipe can operate at all mixing ratios without the aid of gravity. It is observed that the heat transfer characteristics improve with increasing inclination angle. Through the flow images, physical phenomena in the flow passages are defined.
\end{abstract}

Keywords: Binary mixture, Thermal performance, Pulsating heat pipe 


\section{GIRIS}

Gittikçe dijitalleşen dünyada, teknolojik ilerlemenin önündeki engellerden birisi de atık 1S1 problemidir. Sistemlerden etkin bir şekilde uzaklaştırılamayan atık 1S1, performansın düşmesine, güvenlik sorunlarına, ısıl gerilmelere ve dolayısıyla deformasyonlara yol açabilmektedir. Hassas mikro/nano ölçekli üretim tekniklerinin gelişmeye devam ettiği günümüzde, elektronik sistemlerin kapasiteleri artarken, hem kendi hem de yerleștirildikleri hacimlerin boyutları ise küçülmektedir. Dolayısıyla, küçük hacimlerden atık 1sıyı etkin bir şekilde uzaklaştırabilecek, gelişmiş 1sıl kontrol yöntemlerine ihtiyaç duyulmaktadır. Bu noktada, en popüler ve gelecek vadeden tekniklerden biri atımlı 1S1 borularıdır (PHP). Atımlı 1S1 boruları, Akachi [1] tarafindan 1990 yılında literatüre tanıtıldıktan sonra, özellikle klasik 1sı borularından farklı olarak, fitil kullanımı gerektirmemeleri ve sürüklenme ve kılcallık limiti gibi çalışmayı olumsuz etkileyen fiziksel mekanizmalara maruz kalmamaları sebebiyle ön plana çıkmıştır. Üretim kolaylığı, pasif karaktere sahip olmaları ve yüksek 1s1 aktarım kapasitesi gibi avantajlar, atımlı 1sı borularına birçok alanda kullanım potansiyeli sunmaktadır. Uzay uygulamaları (uzay ve havacılık elektroniği) [2], [3]; LED çiplerin soğutulması [4]; elektrikli araç bataryalarının soğutulması [5]; faz değiştiren madde (PCM) destekli güneş enerjili damitıcilarda PCM'de depolanan isının, tuzlu suya aktarımı [6], ilgili potansiyel kullanım alanlarına örnek olarak verilebilir. Üretim, kullanım alanı potansiyeli ve üstün 1sı transfer karakteristikleri gibi avantajlarından dolayı PHP'ler, güncel ve popüler araştırma konularından biridir.

Atımlı 1sı boruları, iş akışkanı ve birbiriyle bağlantılı paralel akış kanalları formunda üretilen konteynır olmak üzere, sadece iki temel bileşenden oluşmaktadır. Temel geometrik yapıdaki bu basitliğe rağmen, atımlı ısı borularının akış yapısı; kaynamalı akış ve yoğuşma süreçleri, atım/salınım hareketleri yapan akış bileşenleri (sıvı yığınlar ve buhar kabarcıkları) ve zaman bağımlı değişiklikler gibi olayları içermesi sebebiyle oldukça karmaşıktır. Dolayısıyla, genel olarak, yapılan çalışmalar, geometri modifikasyonu, akışkan türü ve akışın fiziksel mekanizmasının irdelenmesi (farklı çalışma koşulları altında) ile ilgilidir.

Charoensawan vd. [7] döngü sayısı $(5-23)$, açısal yerleşim $\left(0^{\circ}-90^{\circ}\right)$ ve iş akışkanı $(\mathrm{R}-123$, su ve etanol) türünün kılcal boru formundaki atımlı 1s1 borularının isıl performansına olan etkilerini deneysel olarak incelemiştir. Yer çekimi kuvvetinin isıl performans üzerinde baskın bir rol oynadığını ve isı borusunun yatay konumda çalışabilmesi için belirli bir sayıdan fazla döngüye sahip olması gerektiğini belirtmişlerdir. Kendi çalışma koşulları kapsamında gerekli olan minimum döngü sayısı 16 olarak ifade edilmiştir. Benzer problem Khandekar vd. [8] tarafından da rapor edilmiştir. Beş döngülü kılcal boru tipi atımlı 1sı borusu için R-123, su ve etanol kullanarak yaptıkları deneylerde, 1sı borusunun yatay konumda çalışamadığını ifade etmişlerdir. Jun ve Kim [9] iş akışkanı olarak etanol kullanmış ve $5,10,15$ ve 20 olmak üzere farklı döngü sayılarına sahip kapalı ve açık döngülü PHP'ler ile çalışmışlardır. Kapalı döngülü PHP'lerin açısal yerleşimden $\left(0^{\circ}-90^{\circ}\right)$ bağımsız çalışabilmesi için 20 kadar döngüye ihtiyaç duyduklarını belirtmişlerdir. Az döngü sayıları için ortaya çıkan bu durumun sebebi, akış pasajlarındaki akış kararsılıkları ve basınç pertürbasyon düzeyindeki yetersizliğe atfedilmektedir [7, 10]. İlgili problemi çözmek için Chien vd. [11] tarafindan üniform olmayan atımlı 1S1 borusu geometrisi önerilmiştir. Bu geometride, her bir döngü, farklı kesite sahip paralel kanal çiftinden oluşmaktadır ( $2 \mathrm{~mm}$ x $1 \mathrm{~mm}$ ve $2 \mathrm{~mm}$ x $2 \mathrm{~mm}$ ). Saf su kullanarak yaptıkları çalışmalar sonucunda \%50'den büyük dolum oranlarında (\%60 ve \%70), üniform olmayan 1s1 borusunun yatay konumda bile çalışabildiğini belirtmişlerdir. Chien vd. [11]'den sonra, farklı araştırmacılar da döngülerinde farklı kesite sahip kanallar bulunan üniform olmayan PHP'lerle ilgili çalışmalar yapmıştır. Kwon ve Kim [12], [13] hem tek hem de çok döngülü (beş döngü) üniform olmayan PHP'lerde farklı iş akışkanları (etanol ve/veya FC-72) kullanarak deneysel çalışmalar yürütmüşler ve farklı kesit alanlı paralel kanalların sirkülasyonlu akışı iyileştirdiği, böylece ısıl dirençte $\% 45$ 'e varan azalmanın meydana gelebildiğini belirtmişlerdir. Isıl dirençteki azalmayı, akışkan hareketinin iyileşmesi; akışkan hareketinin iyileşmesini ise kılcallık basınç farkının sürtünme basınç düşüşüne baskın gelmesi ile açıklamışlardır. Wan vd. [14] yaylı çek valf kullandıkları on döngülü atımlı ısı borusunda, yer çekimi, asimetrik 1sıtma ve çek valf olmak üzere üç faktörün bütünleşik etkisini incelemişlerdir. \%70 dolum oranında çalışmışlar ve iş akışkanı olarak de-iyonize su kullanmışlardır. 
Belirtilen üç faktörden herhangi ikisinin kullanımının, ısı borusu performansında artış sağladığı; ancak üçünün birlikte kullanımının ısıl direncin artması gibi olumsuz sonuçlara yol açtığı ifade edilmiştir. Çek valf tarafından yapılan yönlendirme, asimetrik 1sıtma sonucu oluşan akış hareketine ters olduğu zaman konvansiyonel atımlı 1sı borusundan daha yüksek isıl direnç değerleri elde edildiği belirtilmiştir.

Geometrik özelliklerin; PHP performansı, akış yapısı ve çalışma limitleri üzerindeki etkilerini inceleyen çalışmaların yanı sıra, bazı araştırmacılar tarafından PHP'yi oluşturan diğer bileşen olan akışkan türü üzerine odaklanılmıştır. Özellikle, son yıllarda, farklı karışımların PHP'lerin 1sıl karakteristikleri üzerindeki etkilerini inceleyen çalışmalar yapılmaktadır. Bu çalışmalardaki temel amaç, saf akışkanlar üzerine yapılan çalışmalarda ortaya çıkan etkili (sistem performansını artıran) termo-fiziksel özellikleri, akışkanları karıștırarak bir araya getirmektir. Çalışma koşullarına bağlılık, atımlı 1sı borularının akış doğasının karmaşıklığı ve akışkanlar arası etkileşimler geniş bir araştırma alanı oluşturmaktadır.

Zhu vd. [15] düşey olarak konumlandırdıkları (alttan ısıtma modu) kılcal boru tipi PHP'de, iş akışkanı olarak farklı hacimsel karışım oranlarında $(13: 1,4: 1,1: 1,1: 4,1: 13)$ su-aseton akışkan çifti kullanmıştır. Farklı 1sıl yükler ve dolum oranlarında (\%35-\%70) deneysel olarak çalışmışlardır. Karışım içerisindeki suyun, kurumanın önlenmesi konusunda önemli bir rol oynadığını; düşük dolum oranlarında (\%35 ve \%45) su-aseton karışımlarının, genel anlamda, ilgili karışımı oluşturan saf akışkanlara kıyasla daha yüksek ısı transfer performansı sunduğunu, yüksek dolum oranlarında (\%62 ve \%70) ise karışım performansının saf akışkanlara kıyasla düşük olduğunu ifade etmişlerdir. Han vd. [16] kılcal boru türündeki beş döngülü atımlı 1sı borusunda, su bazlı ikili karışımlar (su - etanol, su aseton ve su - metanol) üzerine odaklanmışlardır. Karışımlar için elde edilen sonuçları etkileyen ve faz değişimi sönümleme etkisi (yüksek kaynama noktasına sahip bileșenin, diğer bileşenin yüksek buhar basınc1 sonucu sıv1 fazda kalması) olarak adlandırılan önemli bir fiziksel olay üzerinde durmuşlardır. İkili karışımların düşük (\%35 ve \%45) veya orta düzeyli (\%55) dolum oranlarında daha etkin bir performansa yol açtığını ve faz değişimi sönümleme etkisinin kurumanın önlenmesinde rol oynağını belirtmişlerdir. Cui vd. [17] farklı karışım oranlarına (2:1, 4:1 ve 7:1) sahip metanol bazlı ikili karışımlarla (metanol-aseton, metanol-etanol ve metanol-de-iyonize su) yüklü beş döngülü PHP'nin 1sıl direnç davranışını, \%45 - \%90 arasındaki dolum oranları ve 10W - 100W arasındaki 1sıl yükler için deneysel olarak incelemiştir. Hem kuruma olayının ötelenmesi hem de daha düşük 1sıl dirençlerin elde edilmesi sebebiyle, en etkili karışım \%45 dolum oranındaki (ilgili çalışmadaki en düşük dolum oranı) metanol-su karışımı olarak belirlenmiştir. Temel fiziksel sebepler, faz değişimi engelleme etkisi ve düşük dolum oranı sebebiyle kütle transferiyle ilişkili direncin akış sürücü kuvvetine kıyasla zayıf olması olarak açıklanmıştır. Wang et al. [18], 2:1, 4:1 ve 7:1 hacimsel karışım oranları için aseton-su, aseton-etanol ve aseton-metanol ikili karışımları ile yüklü PHP'nin 1sı transfer performansın $1 \% 45, \% 55, \% 62$ ve $\% 70$ olmak üzere dört farklı dolum oranı için incelemiştir. Diğer çalışmalarla [15]-[18] benzer olarak, nispeten düşük dolum oranında (\%45), zeotropik özelliklerin (bileşenlerin farklı kaynama noktaları) 1sıl performans üzerinde etkili olduğunu; nispeten yüksek dolum oranlarında (\%62 ve \%70) ise yoğunluk ve viskozitenin 1sıl performans üzerinde etkili olduğunu belirtmişlerdir (düşük akış direnci - yüksek ısıl performans ilişkisi). Xu vd. [19] de-iyonize su ve HFE-7100'ün karıştırılmasıyla elde ettikleri zeotropik bir ikili karışımı, iş akışkanı olarak kullanmışlar ve farklı karışım oranları $\left(4: 1,2: 1,1: 1,1: 2\right.$ ve 1:4), eğim açıları $\left(30^{\circ}-90^{\circ}\right)$ ve 1 sıl yüklerde, düz plaka tipi atımlı 1sı borusunun 1sı transfer performansını incelemişlerdir. $\% 50$ olarak tek bir dolum oranında çalışmışlardır. Her iki akışkanın eşit oranlı karışımında, akışkanların emülsiyon oluşturduğunu ve bu sayede daha fazla etkileşim halinde olduklarından, 1sıl karakteristiklerin önemli düzeyde iyileştiğini ifade etmişlerdir. Ayrıca, yer çekimi kuvvetinin de (özellikle düşük ısıl yüklerde) 1sı borusunun çalışmasını etkileyen önemli bir faktör olduğunu belirtmişlerdir.

Atımlı 1sı borularının (PHP) birçok avantajı olmasına rağmen, az döngü sayısına sahip üniform kanallı PHP'lerin yatay konumda çalışamaması, gittikçe minyatürleşen sistemlerin ve uzay-havacılık elektroniği ve dizüstü bilgisayarlar gibi potansiyel kullanım alanlarının önündeki en büyük engellerden birisidir. Bu kapsamda, yukarıda belirtildiği gibi, farklı kesit alanlarına sahip paralel kanal dizisi tasarımı, önemli bir avantaj sunmaktadır. Ayrıca, PHP'lerin performansında, belirleyici rol 
oynayan bir diğer bileşen ise iş akışkanıdır. Atımlı 1sı borusunun düşük 1sıl yüklerde çalışmaya başlaması, geniş bir ısıl güç aralı̆̆ında kabul edilebilir sıcaklık düzeylerinde kalabilmesi ve çalışma esnasında buharlaştırıcı bölgesinden yoğuşturucu bölgesine daha fazla 1sı aktarılabilmesi, uygun iş akışkanı seçimiyle sağlanabilir. Dolayısıyla, iş akışkanı türü, PHP'nin performansı üzerinde son derece belirleyicidir. Bu doğrultuda, yukarıda özetlendiği gibi, son yıllarda, sadece sınırlı sayıdaki çalışmada, ikili karışımlar üzerine odaklanıldığ 1 görülmektedir. Karışım kullanımındaki temel amaç (PHP'lerin çalışma mekanizması açısından) farklı akışkanların üstün özelliklerini bir araya getirmektir.

Farklı kesit alanına sahip paralel kanallardan oluşan düz plaka tipi atımlı 1sı borularında (üniform olmayan PHP), iş akışkanı olarak karışım kullanılmasına yönelik ilk deneysel çalışmalar yazarlar tarafindan (Markal ve Varol [20], [21]) yapılmıştır. Böylece, yukarıda özetlenen iki yaklaşım bir araya getirilmiştir. Buna karşın, atımlı 1sı borularındaki güçlü 1sıl-hidrolik ve geometrik etkileşimler sebebiyle, akış yapısı veya çalışma mekanizması oldukça karmaşı/kompleks bir yapıya sahiptir. Bu nedenle, özellikle üniform olmayan PHP'lerde farklı akışkan çiftleri kullanılarak yeni çalışmaların yapılmasına ve yeni veri tabanlarının literatüre kazandırılmasına ihtiyaç duyulmaktadır. Ayrıca, karışımlara yönelik çalışmalarda, \%30'dan büyük dolum oranlarına odaklanılmıştır. İş akışkanına olan bağımlılı̆̆ın azaltılması için daha düşük dolum oranlarındaki isıl ve hidrodinamik davranışın da analiz edilmesi gerekmektedir. Literatürdeki mevcut eksiklikleri giderecek şekilde, bu çalışmanın amacı, bir döngüsünde iki farklı kesite sahip paralel kanal içeren ve düşük dolum oranında ikili karışımlarla yüklenen düz plaka tipi atımlı 1sı borusunun 1sı transfer performansını ve akış yapısını (akış görüntüleme desteğiyle) deneysel olarak incelemektir. Bu çalışma ile literatürde ilk kez, bir döngüsünde iki farklı kesite sahip kanal bulunan ve etanol (E) - metanol (M) ikili karışımı ile yüklü düz plaka tipi atımlı ısı borusunda, düşük bir dolum oranında deneysel olarak çalışılmıştır. Dolum oranı \%20 olup, toplam sekiz döngüden oluşan 1s1 borusunda, her bir döngüdeki kanal kesitleri (genişlik x yükseklik) $2 \mathrm{~mm}$ x $2 \mathrm{~mm}$ ve $1 \mathrm{~mm}$ x $2 \mathrm{~mm}$ 'dir. Ayrıca, farklı hacimsel karışım oranlarında (E:M = 1:1, 1:2 ve 2:1) çalışılmış ve yüksek hızlı kamera ile saniyede 1000 görüntü alınarak anlık akış görüntüleri sunulmuştur.

\section{DENEY DÜZENEĞİ, TEST BÖLGESİ ve VERİ İSLEME}

\section{A. DENEY DÜZENEĞİ ve TEST BÖLGESİ}

Çalışmalar; test bölgesi, akış sirkülasyon hattı ve görüntüleme ve veri toplama sistemi içeren bir deney düzeneğinde gerçekleştirilmiştir. İlgili düzeneğe ait şematik gösterim ve kullanılan 1sı borusuna ait üç boyutlu çizim, sırasıyla, Şekil 1a ve b'de sunulmuştur. Deney düzeneği, yukarıda da ifade edildiği üzere, üç temel bölüm üzerinden incelenebilir: (1) Akış görüntüleme ve veri toplama bölümü; yüksek hızlı kamera (ve kendi yazılımı), 1şık kaynağı, veri toplama sistemi (sıcaklık ölçümleriyle ilişkili) ve bilgisayarlardan oluşmaktadır. (2) Test bölgesi; atımlı 1sı borusu, 1sı borusunun yoğuşturucu bölgesiyle irtibatlı ısı alıcı, buharlaştırıcı bölgesiyle ilişkili ısıtıcı plaka, ilgili parçaların montajını sağlayan teflon parça ve isıtıcı plakaya yerleştirilen kartuş isıtıcıların bağlı olduğu güç kaynağından oluşmaktadır. (3) akış sirkülasyon hattı ise yoğuşturucu bölümünün hemen altına yerleştirilen 1s1 alıcıyla irtibatlı ve 1sı alıcıdaki soğutma suyu akışını sağlayan borulama hattıdır. İstenilen debi ve sıcaklıkta akışkanın sürekli akışını sağlayacak şekilde; sabit sıcaklık banyosu, mikro pompa, akış ölçer ve sıcaklık ölçüm elemanlarından (T-tipi termoelemanlar) oluşmaktadır. Deney düzeneği ve sistemdeki cihazlara ait detaylı bilgiler için yazarların önceki çalışmalarına bakılabilir [20]-[22]. Deneylerin yapılışı ve test bölgesine ait detaylar aşağıda belirtilmiştir.

- Deneylere başlamadan önce, atımlı 1s1 borusunun vakumlama işleminin yapılması gerekmektedir. Bu kapsamda bir vakum pompası ile PHP'nin iç hacmi vakumlanır. 


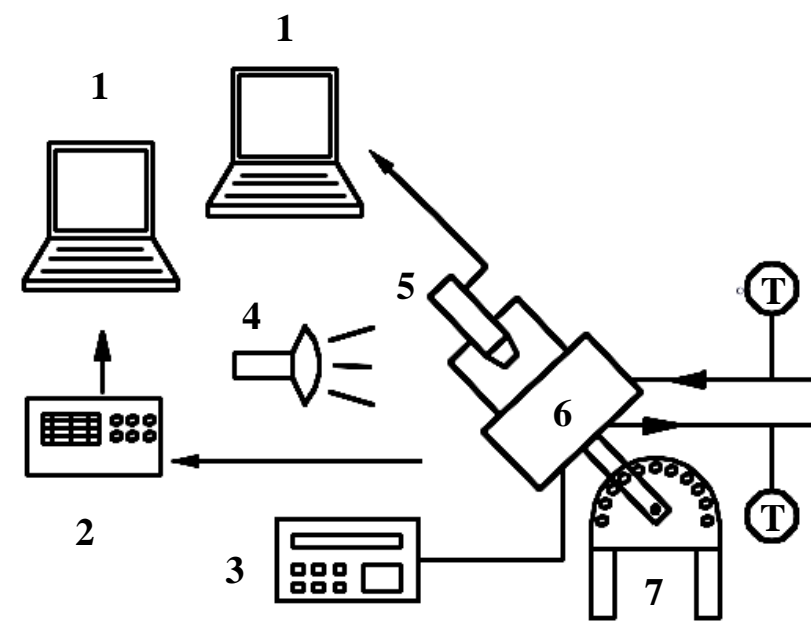

PHP'nin açısal yerleşimi
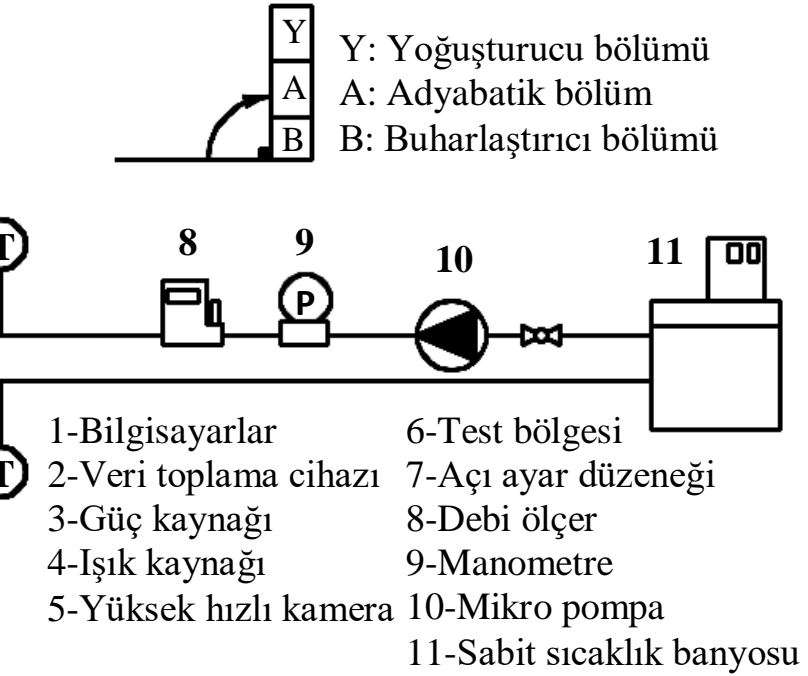

(a)

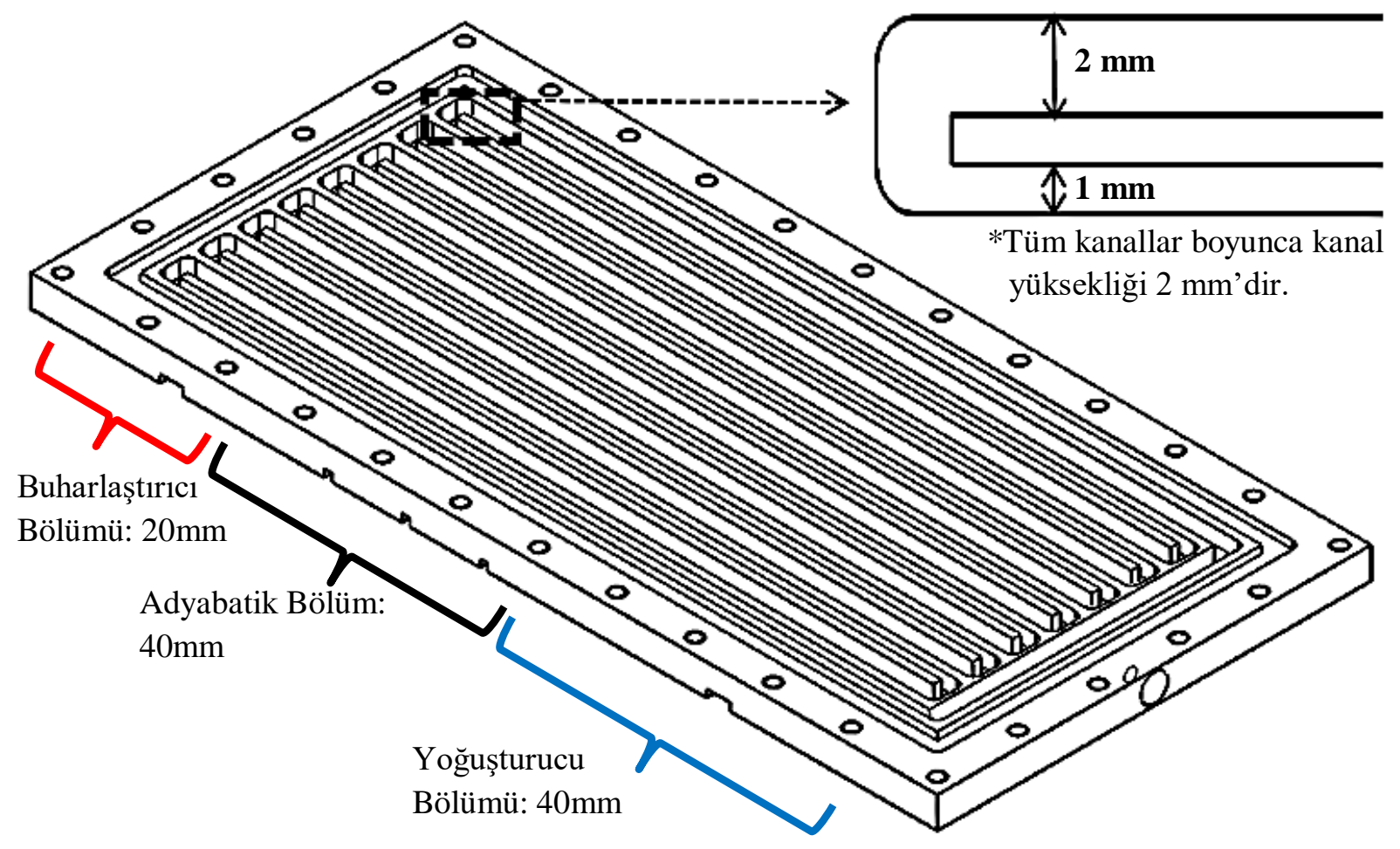

(b)

Şekil 1. (a) Deney düzeneğinin şematik resmi ve (b) kullanılan ısı borusuna ait üç boyutlu çizim

- Akış döngü hattı aktif hale getirilir: Şekil 1b'de görüldüğü gibi PHP; buharlaştırıcı, adyabatik ve yoğuşturucu olmak üzere üç farklı bölümden oluşur. Yoğuşturucu bölümü, akışkanın, buharlaştırıcı bölümünden aldığı 1sıyı dışarıya aktardığı bölümdür. Burada dışarıdan kasıt bir 1S1 alıcıdır. Isı alıcı olarak iki parçalı bir yapı kullanılmıştır. $10 \mathrm{~mm}$ kalınlığındaki polikarbon bir plakaya akış kanalları açılmış ve $2 \mathrm{~mm}$ kalınlığındaki bakır bir plaka ile montajı yapılmıştır. Isı alıcının bakır yüzeyi, PHP'nin yoğuşturucu olarak adlandırılan bölümünün altına yerleştirilmiştir. Böylece, etkin bir ısı alıcı tasarlanabilmiştir. Isı alıcı, teflon gövdenin içine açılan yuvaya yerleştirilmiş olup, sistemin montajlı halinde, PHP sadece bakır yüzey ile 
temas etmektedir. Isı alıcı borulama hattı içinde yer almaktadır. Borulama hattında, Şekil 1a'da görüldüğü gibi, sirkülasyon suyunun sıcaklık ve debisini kontrol edebilecek cihazlar bulunmaktadır. Isı borusunun yoğuşturucu bölümünden aktarılan 1sıyı belirlemek için 1sı alıcı içinden geçen akışkanın debisinin ve giriş-çıkış sıcaklık değerlerinin bilinmesi gerekmektedir. $\mathrm{Bu}$ nedenle, $1 \mathrm{~s} 1 \mathrm{al} 1 \mathrm{c} 1$ içerisinden sabit debide $(20 \mathrm{ml} / \mathrm{dk})$ ve giriş sıcaklığında $\left(20^{\circ} \mathrm{C}\right)$ sirkülasyon suyu geçirilmektedir. Isı alıcının giriş ve çıkışına birer adet T-tipi termoeleman yerleştirilmiştir. Bu termoelemanlar veri toplama sistemine bağlidır.

- İstenilen dolum oranındaki iş akışkanı PHP içerisine doldurulur: İş akışkanı olarak, farklı hacimsel oranlarda karıştırılan metanol-etanol akışkan çiftleri kullanılmıştır.

- Is1 borusu istenilen eğim açısına ayarlanır: Test bölgesi, 15 derecelik açılarla hareket ettirilebilen bir düzenek üzerine konumlandırılmıştır. Bu sayede, bu çalışma kapsamında incelenen $0^{\circ}$ (yatay konum), $45^{\circ}$ ve $90^{\circ}$ (buharlaştırıcının altta yer aldığı düşey konum) eğim açıları kolay bir şekilde ayarlanabilmiştir.

- Güç kaynağı aktif edilerek, PHP'ye ısıl güç uygulanır: Yukarıda da belirtildiği üzere PHP'nin bölümlerinden birisi de buharlaştırıcı bölümüdür. PHP'nin buharlaştırıcı bölümü, bakırdan imal edilmiş bir 1sıtıcı plaka üzerine yerleştirilmiştir. İlgili plaka içerisine iki adet kartuş 1sıtıcı yuvası açılmış ve buralara kartuş 1sitıcılar yerleştirilmiştir. Kartuş 1sıtıcılar, bir güç kaynağı ile bağlantılı olup, PHP hassas bir şekilde istenilen 1sıl güç değerine maruz bırakılabilmektedir. Burada, uygulanan 1sıl güç açısından, bir sıcaklık üst limiti $\left(110^{\circ} \mathrm{C}\right)$ kabul edilmiştir. Isıl gücün ilk değeri $5 \mathrm{~W}$ 'tır. $5 \mathrm{~W}$ değerinde sistem kararlı hale gelene kadar beklenir. Sonra sıcaklık ölçümleri ve eş zamanlı akış görüntüleri alınır. Isıl güç $5 \mathrm{~W}$ artırılarak benzer işlemler tekrarlanır. Her bölümde 3 termoeleman vardır. Buharlaştırıcı bölümündeki ortalama sıcaklık değeri yaklaşık $110^{\circ} \mathrm{C}$ olduğu zaman ilgili deney sonlandırılır. $\mathrm{Bu}$ aşamada çıkan isıl güç değeri, üst sıcaklık limiti kabulümüz doğrultusunda, ilgili çalışma koşulları altındaki maksimum 1 sıl güç değerine karşılık gelir.

- Diğer bir çalışma koşuluna geçilerek, yukarıda belirtilen prosedür tekrarlanır. Bu çalışmada, üç farklı eğim açısında, üç farklı hacimsel karışım oranında, tek bir dolum oranında ve farklı 1sıl yükler altında çalışılmıştır.

Çalışmada kullanılan ısı borusu; $4 \mathrm{~mm}$ kalınlığında ve toplam uzunluğu $116 \mathrm{~mm}$, genişliği ise 55.5 mm olan bakır bir plaka üzerine açılan $2 \mathrm{~mm}$ derinliğinde birbiriyle bağlantılı kanallar içermektedir. Kanalların olduğu bölgenin toplam uzunluğu ve genişliği ise, sırasıyla, $100 \mathrm{~mm}$ ve $39.5 \mathrm{~mm}$ 'dir. Is1 borusu hem sızdırmaz bir iç hacim içermeli, hem de akış görüntülemeye olanak sunmalıdır. $\mathrm{Bu}$ nedenle, belirtilen bakır plakanın üzeri şeffaf cam kapak ile kapatılmıştır. Hem sıcaklık ölçüm elemanlarının yerleştirilebilmesi hem de akış görüntüleme için gerekli olan yapının sağlanabilmesi için bakır plakanın toplam kalınlığı, genişliği ve uzunluğu akış kanal bölgesine kıyasla daha fazladır. Bu çalışmada kullanılan ısı borusu, asimetrik kanal formuna sahip düz plaka tipi kapalı döngülü atımlı 1sı borusudur. Isı borusu toplam sekiz döngü veya bir başka ifade ile birbiriyle bağlantılı on altı paralel kanaldan oluşmaktadır. Bir döngüde yer alan kanal çiftlerinden biri $2 \mathrm{~mm}$ genişliğinde, diğeri ise 1 mm genişliğinde olup, paralel kanalların kesit alanları birbirinden farklıdır (Şekil 1b). Deney düzeneği ve test bölgesine ait detaylar, yazarların önceki çalışmalarında kapsamlı bir şekilde sunulmuştur [20][22].

\section{B. HESAPLAMA YÖNTEMİ ve DENEYSEL BELİRSIZLLIK DÜZEYLERİ}

Deneysel hesaplama adımları, atımlı 1sı borusu literatüründe [11], [23], genel kabul gören ve yazarların önceki çalışmalarında da [20]-[22] belirtilen formda sunulmuştur. Bu kapsamda, bir PHP'nin en önemli ssıl performans göstergelerinden biri toplam 1sıl direnç veya sadece 1sıl direnç olarak adlandırılan terimdir ve aşağıdaki gibi hesaplanır:

$$
R_{t h}=\frac{\left(T_{e}-T_{c}\right)}{Q}
$$


Burada, $T_{e}$ ve $T_{c}$, sırasıyla, buharlaştırıcı ve yoğuşturucudaki termoelemanlardan okunan sıcaklıkların ortalamasını, bir başka ifade ile ortalama buharlaştırıcı ve yoğuşturucu sıcaklıklarını temsil etmektedir. Paydada yer alan $Q$ terimi ise, güç kaynağı ile uygulanan 1sıl güç ile soğutma suyu (1s1 alıcıdan geçen) tarafindan uzaklaştırılan bir başka ifade ile yoğuşturucu bölgesinden 1sı alıcıya aktarılan isıl gücün ortalama değerini ifade etmekte olup, aşağıdaki gibi gösterilir:

$Q=\frac{Q_{i}+Q_{r}}{2}$

Burada, güç kaynağı ile uygulanan 1sıl güç $Q_{i}$; yoğuşturucu bölgesinden 1s1 alıcıya aktarılan 1sıl güç ise $Q_{r}$ ile gösterilmiştir. Eşitlik 2'nin kullanılmasıyla, 1sıl direnç hesabında 1sıl kayıplar da dikkate alınmıştır [10]. Güç kaynağı ile uygulanan ısıl güç değeri, ilgili cihazın dijital ekranından hassas bir şekilde ayarlanabilmektedir. Isı alıcıya aktarılan 1sıl güç ise, 1sı alıcı giriş ve çıkışındaki su sıcaklığı ve suyun debisi kullanılarak aşağıdaki gibi belirlenir:

$Q_{r}=\dot{m} c_{p}\left(T_{h o}-T_{h i}\right)$

Burada; $T_{h o}$ ve $T_{h i}$, sırasıyla, soğutma suyunun 1sı alıcıdan çıkış ve 1 sı alıcıya giriş sıcaklıkları; $\dot{m}$ ve $c_{p}$ ise, sırasıyla, soğutma suyunun kütlesel debi ve özgül ısısını ifade etmektedir.

Isıl dirence yönelik ifadeler, yukarıda verilmiştir; ancak açıkça belirtilmelidir ki PHP'ler için isıl performans göstergesi sadece 1sıl direnç değildir. Atımlı 1s1 borusunun çalışmaya başlama performansı, buharlaştırıcı sıcaklığı ve (tanımlı üst sıcaklık limiti dahilinde) maksimum isıl güç değeri de diğer performans göstergeleri olarak değerlendirilmelidir.

Çalışma kapsamında belirsizlik analizi de yapılmıştır. Belirsizlik analiziyle ilgili tüm detaylar ve formüller yazarların önceki çalışmasında [21] belirtilmiştir. Burada, bu çalışmaya özgü veri tabanı üzerinden, sadece belirsizlik değerleri sunulacaktır. Hesaplama prosedüründen de görüldüğü üzere, türetilen tek parametre isıl dirençtir ve Kline ve McClintock [24] tarafından tanımlanan belirsizlik analizine göre, ısıl direnç için hesaplanan belirsizlik düzeyi aralığ $\pm \% 4.1-\% 5.6$ 'dır.

\section{SONUCLAR VE TARTISMA}

Çalışma kapsamında; iş akışkanı olarak etanol ve metanol karışımının kullanıldığı, farklı kesit alanına sahip paralel kanallardan oluşan (bir döngüde farklı kesite sahip kanal çifti) düz plaka tipi atımlı 1s1 borusunda farklı hacimsel karışım oranları ( $\mathrm{E}: \mathrm{M}=1: 1,1: 2$ ve $2: 1)$, eğim açıları $\left(0^{\circ}, 45^{\circ}\right.$ ve $\left.90^{\circ}\right)$ ve 1 sıl yükler altında deneyler yapılarak; karışım oranı, ssıl yük ve eğim açısının PHP performansı üzerindeki tekil ve/veya bütünleşik etkileri incelenmiştir. Dolum oranı \%20 olacak şekilde sabit tutulmuş olup, akış davranışı ve temel fiziksel mekanizma, yüksek hızlı akış görüntüleri (1000 görüntï/saniye) aracılığıyla analiz edilmiştir. Elde edilen bulgular ve ilgili tartışma aşağıda alt başlıklar halinde sunulmuştur.

\section{A. ISIL GÜÇ ve KARIŞIM ORANI ETKİSİ}

Şekil 2a-f'de, PHP'nin 1sıl direnç ve buharlaştırıcı sıcaklığının farklı hacimsel karışım oranları için ısıl güç ile değişimi verilmiştir. İlgili grafikler, $0^{\circ}$ (Şekil 2a, b) $45^{\circ}$ (Şekil 2c, d) ve $90^{\circ}$ (Şekil 2e, f) eğim açıları için sunulmuştur. Öncelikle 1sıl güç etkisi üzerinde durulacaktır. Bu kapsamda, genel bir davranış olarak, belli bir ısıl güç değerine kadar yatay eğilim gösteren ısıl dirençte, ani bir azalma meydana gelmekte ve devamında 1 sıl direnç değerleri artan ısıl güç ile azalmaktadır. Isıl dirençte görülen ani azalma, PHP'nin çalışmaya başladığının göstergesidir. Ani düşüşün görece daha erken gerçekleşmesi veya bir başka ifade ile daha düşük 1sıl güç değerinde meydana gelmesi, bir PHP için çalışmaya başlama performansının görece daha iyi olduğu anlamına gelir. Burada, altı çizilmesi 
gereken noktalardan birisi, PHP'nin çalışmasıyla ilgili veya daha açık bir ifade ile nasıl çalıştığı ile ilgili kesin yargıya varabilmek için akış görüntüleme çalışmalarının yapılması gerektiğidir. Özellikle, literatürde başla-dur hareketi [11, 25] olarak tanımlanan fiziksel olaylar sebebiyle, akış1 görüntülemeden salt veri değişiminden çıkarılacak sonuçlar hatalı yorumlara yol açabilir.

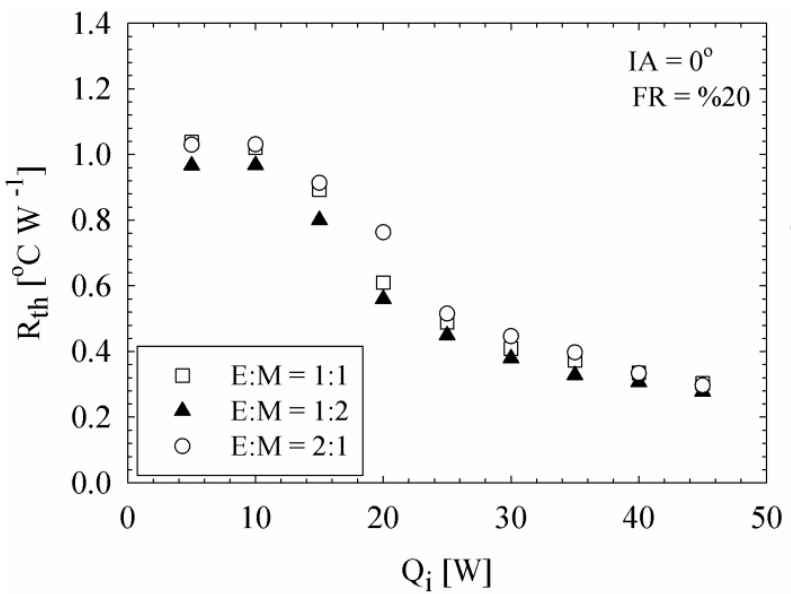

(a)

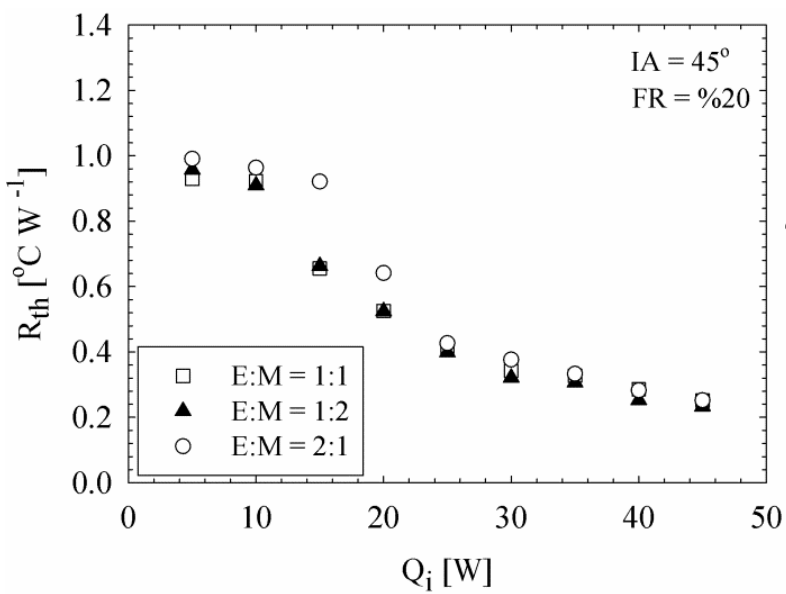

(c)

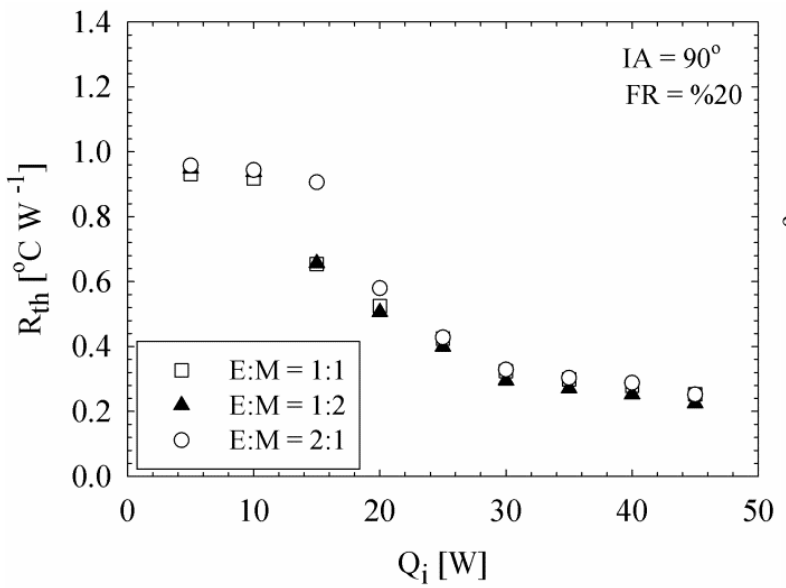

(e)

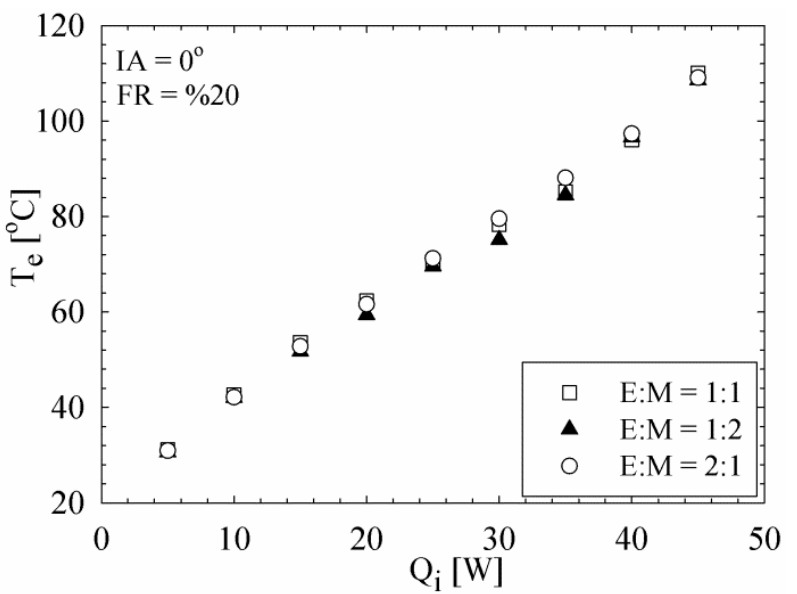

(b)

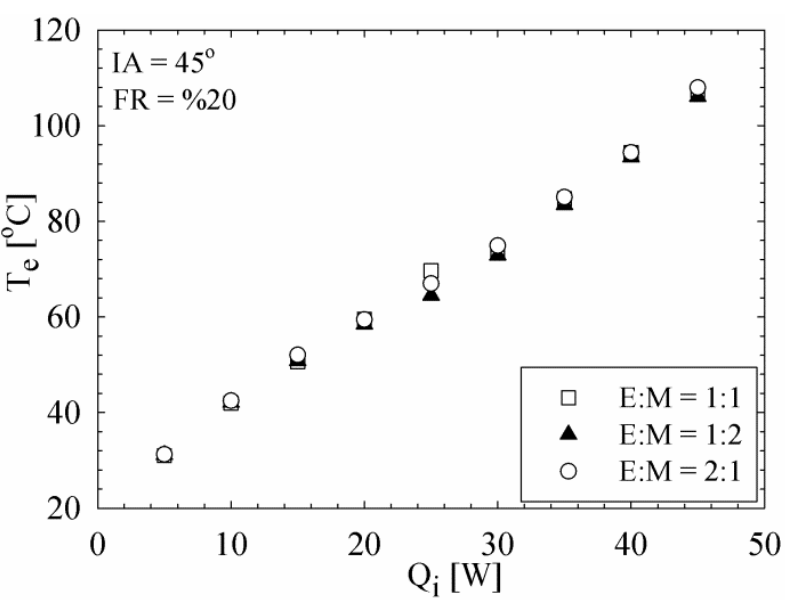

(d)

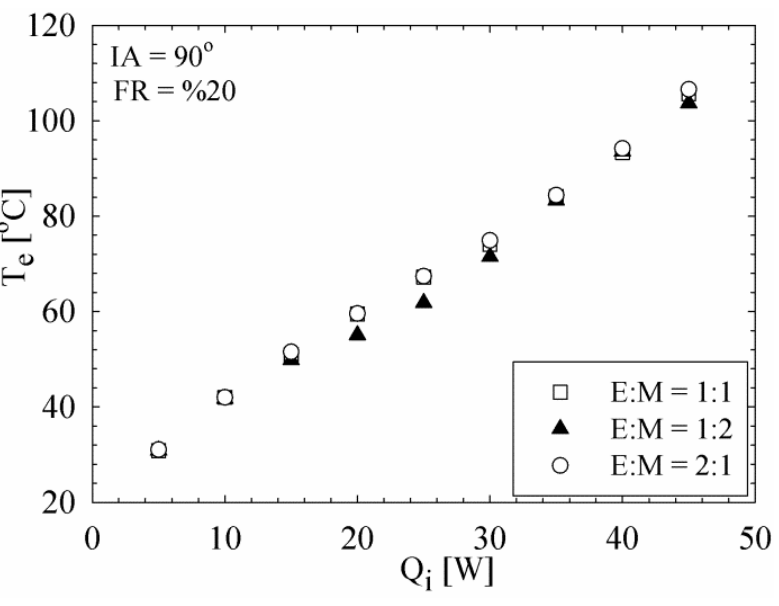

(f)

Şekil 2. PHP'nin ısıl direnç ve buharlaştırıcı sıcaklı̆̆ının farklı karışım oranlarn için ısıl güç ile değişimi: (a) $R_{t h}, 0^{\circ},(\boldsymbol{b}) T_{e}, O^{\circ},(\boldsymbol{c}) R_{t h}, 45^{\circ},(\boldsymbol{d}) T_{e}, 45^{\circ},(\boldsymbol{e}) R_{t h}, 90^{\circ}$ ve $(f) T_{e}, 90^{\circ}$ 
Yukarıda, genel karakter olarak, ısıl direncin artan ısıl güç ile azaldığı belirtilmişti. Basit bir şekilde ifade etmek gerekirse, atımlı 1sı boruları, 1sıl olarak tetiklenen cihazlardır ve ssıl etkiler sonucu açığa çıkan basınç farkları ve basınç çalkantıları sonucu çalışırlar (atım, salınım ve kısmi sirkülasyon hareketinin kaynağı). Dolayısıyla, literatürde de belirtildiği üzere [11], [14], [26], bu sonuç, artan 1sıl yük ile sürücü kuvvetin iyileşmesi ve buna bağlı olarak sirkülasyon hızının artması ile açıklanabilir. Buna karşın, atımlı 1sı borularında salt tek fazlı bir akışın olmadığı vurgulanmalıdır. Bu sebeple, 1sıl güç artışıla, akışkan ve geometrik özelliklerin bütünleşik etkisinin sonucu olarak ortaya çıkan kabarcık dinamiği ve akış desenleri de sonuçlar üzerinde etkin rol oynar. Bu kapsamda, Şekil 2e ve f'deki $\mathrm{IA}=90^{\circ}$ ve E:M=1:1 koşulu için, $20 \mathrm{~W}$ ve $45 \mathrm{~W}$ için elde edilen görüntüler Şekil $3 \mathrm{a}$ ve b'de verilmiştir.

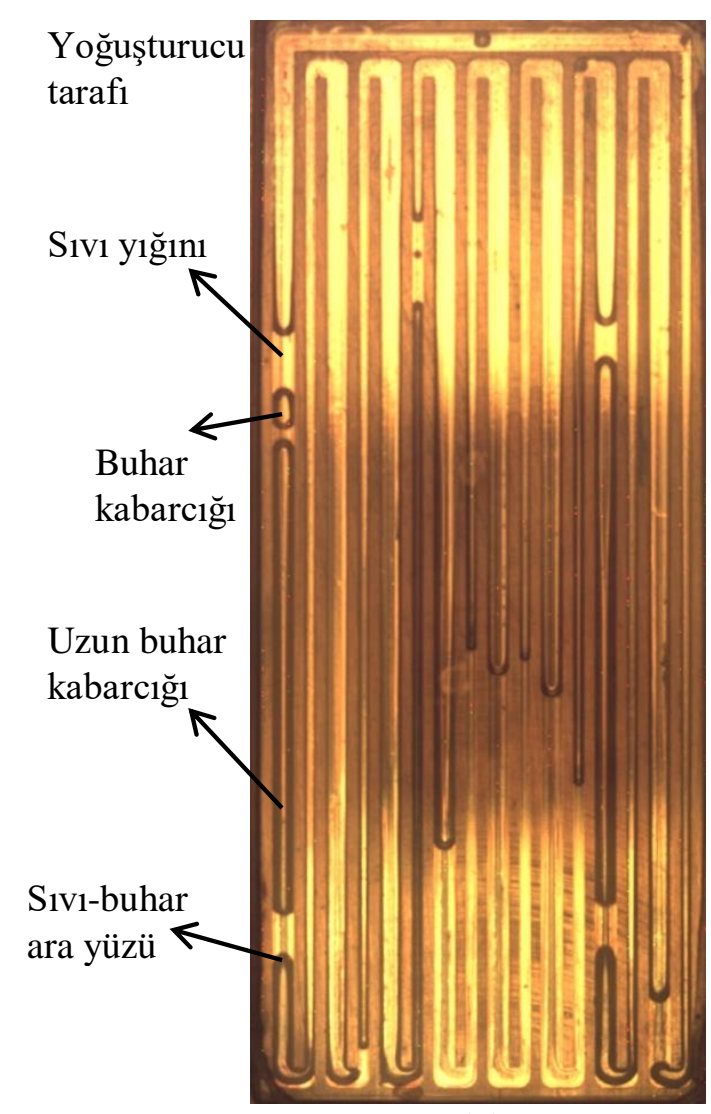

(a)

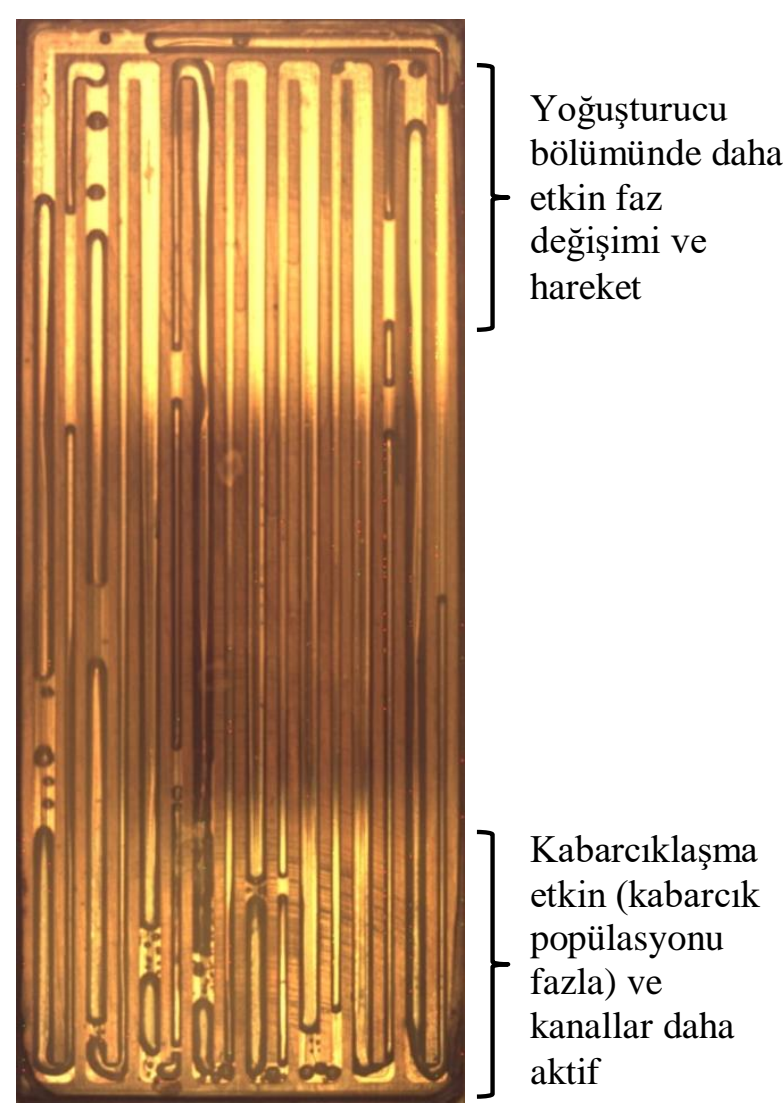

(b)

Şekil 3. $I A=90^{\circ}$ ve E:M=1:1 koşullart için akış görüntüleri: (a) $20 \mathrm{~W}$ ve (b) $45 \mathrm{~W}$

Şekil 3'teki görüntülerde üst bölüm yoğuşturucu tarafinı, alt bölüm ise buharlaştırıcı (1sıl gücün uygulandığı bölüm) tarafını göstermektedir. Isıl yükün 20W'tan 45W'a artırılmasıyla akış yapısında belirgin fiziksel değişimler meydana gelmektedir. Buharlaştıııcı bölgesinde kabarcıklı kaynama olayı iyileşmekte ve çok daha fazla sayıda buhar kabarcığı oluşmaktadır. Ayrıca, daha yüksek sıcaklık altında oluşan buhar kabarcıkları sıvı içerisinde sönümlenmeden veya diğer buhar kabarcıklarına karışmadan varlığını sürdürebilmektedir. Şekil 3b'de, iki buhar kabarcığı arasında bulunan sıvı yığını içindeki mikro kabarcıklar, bu durumu net olarak göstermektedir. Kabarcık popülasyonunun artması ve ayrık (nispeten daha küçük) buhar kabarckklarının kanallar içinde daha hızlı ve bağımsız hareket edebilmesi; (1) buharlaştırıcı bölümünden ısının daha etkin bir şekilde alınması, (2) akışın daha etkin bir şekilde karıştırılarak taşınımın iyileştirilmesi ve (3) buharlaştırıcı bölgesinden alınan ısının yoğuşturucu bölgesine daha etkin bir şekilde aktarılmasını sağlar. İnce sıvı filmiyle çevrili ayrık buhar kabarcıklarının yoğuşturucu bölgesinde daha fazla bulunması veya bir başka ifade ile daha aktif bir şekilde yoğuşturucu bölgesinde hareket etmesi, yoğuşturucu bölümdeki faz değişim proseslerini ve dolayısıyla 1sı alıcıya olan 1sı geçişini daha etkin hale getirmektedir. Dolayısıyla yukarıda da 
belirtildiği üzere, artan ısıl güç sonucu akışın hızlanmasına ek olarak; akış desenleri ve kabarcık dinamiği de ısıl direncin azalmasında ve ısıl performansın artmasında önemli rol oynamaktadır.

Şekil 2'den görüldüğü üzere, saf akışkanların karışım içindeki hacimsel oranı da sonuçlar üzerinde önemli etkiye sahiptir. Yatay konumda (Şekil2a-b) daha belirgin olmakla birlikte, karışım içindeki metanol oranının artması ile 1sı1 performansın arttığı görülmektedir. Buradaki değerlendirme, 1sıl direnç, çalışmaya başlama performansı ve buharlaştırıcı sıcaklığı üzerinden yapılmıştır. Tüm açısal yerleşimlerde, genel karakter olarak, en düşük 1sıl direnç ve buharlaştırıcı sıcaklığ değerleri $\mathrm{E}: \mathrm{M}=1: 2$ için elde edilmiştir. Buna karşın en yüksek ssıl direnç ve buharlaştırıcı sıcaklığı değerleri ise $\mathrm{E}: \mathrm{M}=2: 1$ karışımı kullanıldığında elde edilmiştir. Ayrıca $\mathrm{E}: \mathrm{M}=1: 2$ ve $\mathrm{E}: \mathrm{M}=1: 1$ karışımları ile yüklenen isı borusu $15 \mathrm{~W}$ 1sıl yük altında çalışmaya başlarken; E:M=2:1 akışkanı ile yüklü 1sı borusu 20W'ta çalışmaya başlamaktadır. İlgili ısıl güç değerleri, belirtilen koşullar için kritik ssıl güç değerleri olarak adlandırılabilir. Sonuçların altında yatan fiziksel mekanizmayı tam olarak açıklayabilmek için akışkan özellikleri ve akış görüntülerinin göz önüne alınması gerekmektedir. Bu kapsamda, öncelikle, Tablo 1'de karışımı oluşturan her iki akışkana ait önemli termo-fiziksel özellikler sunulmuştur.

Tablo 1. Karışıımı oluşturan akışkanlara ait önemli özellikler.

\begin{tabular}{|c|c|c|c|c|c|c|c|c|}
\hline \multicolumn{9}{|c|}{ Özellikler (1 atm’de) } \\
\hline Akışkan & $\begin{array}{c}\text { Kaynama } \\
\text { Noktası } \\
\left({ }^{\circ} \mathrm{C}\right)\end{array}$ & $\begin{array}{c}\text { Dinamik } \\
\text { viskozite } \\
\left.(\mathbf{x 1 0})^{3}\right) \\
(P a s)\end{array}$ & $\begin{array}{c}\text { Buharlaşma } \\
\text { gizli IsIsI } \\
\left(k J k^{-1}\right)\end{array}$ & $\begin{array}{c}\text { Yüzey } \\
\text { gerilmesi } \\
\left(\mathbf{x 1 0 ^ { 3 }}\right) \\
\left(N m^{-1}\right)\end{array}$ & $\begin{array}{c}\text { Isıl } \\
\text { iletkenlik } \\
\left(W m^{-1}{ }^{\circ} C^{-1}\right)\end{array}$ & $\begin{array}{l}\text { Yoğunluk } \\
\left(\mathrm{kg} \mathrm{m}^{-3}\right)\end{array}$ & $\begin{array}{l}\text { Özgül ISI } \\
\left(\mathrm{kJ} \mathrm{kg}^{-1}\right. \\
\left.{ }^{\circ} \mathrm{C}^{-1}\right)\end{array}$ & $\begin{array}{c}(\mathbf{d P} / \mathbf{d T})_{\text {sat }} \\
\left(\mathbf{x 1 0 ^ { 3 }}\right) \\
\left(P a^{o} C^{-1}\right)\end{array}$ \\
\hline Etanol & 78.3 & 1.15 & 846 & 22.8 & 0.172 & 789 & 2.39 & 4.2 \\
\hline Metanol & 64.7 & 0.6 & 1101 & 22.6 & 0.212 & 791 & 2.48 & 6.5 \\
\hline
\end{tabular}

Açıklamalar:

$(\mathrm{dP} / \mathrm{dT})_{\text {sat }} 80^{\circ} \mathrm{C}$ için; diğer tüm özellikler ise $20^{\circ} \mathrm{C}$ için yazılmıştır [27].

Tablo 1'den görüldüğü üzere, metanolün buharlaşma gizli 1sıs1, $(\mathrm{dP} / \mathrm{dT})_{\text {sat }}$ değeri ve 1s1l iletkenliği etanole kıyasla yüksekken; dinamik viskozitesi ve kaynama noktası düşüktür. Buna karşın, her iki akışkanın da yüzey gerilmesi, yoğunluk ve özgül 1sı değerleri birbirine oldukça yakındır. Ayrıca, etanol ve metanol birbiriyle karışabilir ve çalışma koşulları altında zeotropik özellikte (kaynama noktası sabit olmayan) bir karışım oluştururlar. Dolayısıyla, Han vd. [16] tarafindan da belirtildiği üzere, zeotropik karışımlar için ısı transfer mekanizması ve akış yapısı çok daha karışıktır. Bileşenler arasındaki moleküler etkileşimler ve tekil olmayan termo-fiziksel özellikler bu durumda önemli rol oynamaktadır. Ancak, saf akışkanların termo-fiziksel özellikleri, sonuçların niteliksel olarak değerlendirilmesinde güvenilir bir araçtır. Dinamik viskozitenin düşük olması, mekanik enerji kaybının azalması ve dolayısıyla performansın artması anlamına gelir. Atımlı 1s1 boruları, temelde basınç farkı prensibine göre çalışan cihazlardır. Bu sebeple, $(\mathrm{dP} / \mathrm{dT})_{\text {sat }}$ değerinin yüksek olması, görece düşük sıcaklıkta, yüksek basınç farkı anlamına geleceği için PHP performansını artıcı yönde etki edecektir. Zhu vd. [15] tarafindan da ifade edildiği üzere, buharlaşma gizli isısının yüksek olması, buharlaştırıcı bölgesinde 1sının daha iyi absorbe edilmesi anlamına gelir. Dolayısıyla, yüksek gizli 1sı, hem daha düşük buharlaştırıcı sıcaklığı, hem de daha fazla miktarda isıl enerjinin yoğuşturucu bölgesine aktarımı anlamına gelir (akışkanın yoğuşturucu bölgesine hareketi sonucunda). Isı iletim katsayısının artması, iletimle 1sı transferinin iyileşmesi anlamına gelir. Termo-fiziksel özelliklerin yukarıda belirtilen katkılarından dolayı, karışım içerisindeki metanol oranının artışı ile 1sıl performansın iyileşmesinin temel sebepleri büyük ölçüde anlaşılmaktadır. Buna karşın, akış görüntüleri ile fiziksel mekanizmanın daha detaylı incelenmesi önem arz etmektedir. Bu kapsamda, Şekil 4a ve b'de, $I A=90^{\circ}$ ve $25 \mathrm{~W}$ koşulları altında, sırasıyla, E:M=1:2 ve E:M=2:1 karışımlarına ait akış görüntüleri sunulmuştur. Akış desenlerinin genel görünümü, belirtilen koşullar için, birbirine yakındır. Buradaki temel faktörlerden biri, her iki akışkanın yüzey gerilmesi değerinin, dolayısıyla da, kabarcık yoğunluğunun birbirine yakın olması şeklinde ifade edilebilir. Genel olarak, uzun kabarcıklı akış deseninin ve/veya kısmi halkasal akış deseninin baskın olduğu görülmektedir. Şekil 4 'te görülen koyu çizgilerle çevrili bölümler, buhar kabarcıklarını göstermektedir. Koyu çizgiler, ilgili buhar kabarcığını çevreleyen sıvı filmidir. Dolayısıyla, etkin olan 1sı transfer mekanizmalarından birisi de 
ince film buharlaşmasıdır. Şekil 4'teki koşullarda, ısı borusunun düşey olarak konumlandırılmış olması sebebiyle (yer çekimi kuvvetinin etkisiyle) sıvının bir miktarının buharlaştırıcı bölgesinde (alt bölüm) toplandığına ve üst bölgelerin çoğunlukla buharla kaplı olduğuna dikkat edilmelidir (dolum oranının \%20 gibi oldukça düşük bir değerde olduğu önünde bulundurulmalıdır). Buna karşın, diğer önemli termo-fiziksel özelliklerin farklılıklarının sebep olduğu fiziksel olaylar, sonuçlar üzerinde belirleyici rol oynamaktadır. Metanolün fazla olduğu koşulda (Şekil 4a), dar kanallarda, daha baskın bir şekilde hızlı kabarcık büyüme kararsızlığı oluşmaktadır. Bu olay, temelde buharlaştırıcı bölümü olmak üzere, eksenel iletim ve akış bileşenlerinin 1S1 aktarımı sonucu adyabatik bölgede de gerçekleşmektedir. Oluşan kabarcık, aniden genişlemekte ve kanal kesiti küçük olduğu için sıkışarak her iki yönde de büyümeye çalışmaktadır. Böylece, hem buharlaştırıcı hem de yoğuşturucu tarafina doğru farklı oranlarda basınç kuvveti uygulanır (yoğuşturucu tarafına daha yüksek düzeyde). Metanolün kaynama noktasının etanole kıyasla düşük olması ve $(\mathrm{dP} / \mathrm{dT})_{\text {sat }}$ değerinin ise belirgin bir şekilde yüksek olmasının, hızlı kabarcık büyüme kararsızlığı olayının daha etkin gerçekleşmesi üzerindeki rolü büyüktür. Atımlı ısı borularına özgü olarak, kanal içerisinde, yerel basınç değerlerinin zaman bağımlı olarak ani şekilde değiştiği de (artıp/azaldığı) göz önünde bulundurulmalıdır. Ayrıca, metanolün $(\mathrm{dP} / \mathrm{dT})_{\text {sat }}$ değerinin yüksek olması, buharlaştırıcı bölümünde oluşan buhar kabarcıklarının, verilen bir sıcaklık değeri için (doymuş koşullarda) daha yüksek basınç kuvveti uyguladığı anlamına gelir. Buna ek olarak, metanolün dinamik viskozitesinin, etanolün dinamik viskozite değerinin yaklaşık \%50'si kadar olması sebebiyle, buhar kabarcıkları arasında kalan sıvı yığınlar, kanallar içerisinde daha kolay hareket eder (mekanik enerji kaybı azalır). Metanolün hem kaynama noktasının düşük olması, hem de buharlaşma gizli ısısının yüksek olması sebebiyle, daha erken ve etkin oluşan buhar kabarcıkları, buharlaştırıcı bölgesinde daha fazla ısıyı absorbe eder. Ayrıca, dinamik viskozite ve $(\mathrm{dP} / \mathrm{dT})_{\text {sat }}$ değerleriyle ilgili avantajlarının da etkisiyle, birim zamanda yoğuşturucu bölgesine doğru daha fazla miktarda 1sı aktarılabilir. Bu detaylı analizlerden dolayı, Şekil 4 'te verilen koşullar için, $\mathrm{E}: \mathrm{M}=1: 2$ 'nin 1 ssıl direnci ve buharlaştırıcı sıcaklığı, $\mathrm{E}: \mathrm{M}=2: 1$ 'e kıyasla, sırasıyla, yaklaşık $\% 7$ ve $5.6^{\circ} \mathrm{C}$ daha düşüktür. Çalışma kapsamındaki tüm veri tabanı üzerinden değerlendirildiğinde ise $\mathrm{E}: \mathrm{M}=1: 2$ 'nin 1sıl direnci E:M=2:1'e kıyasla yaklaşık \%39'a kadar daha düşük değer alabilmektedir.

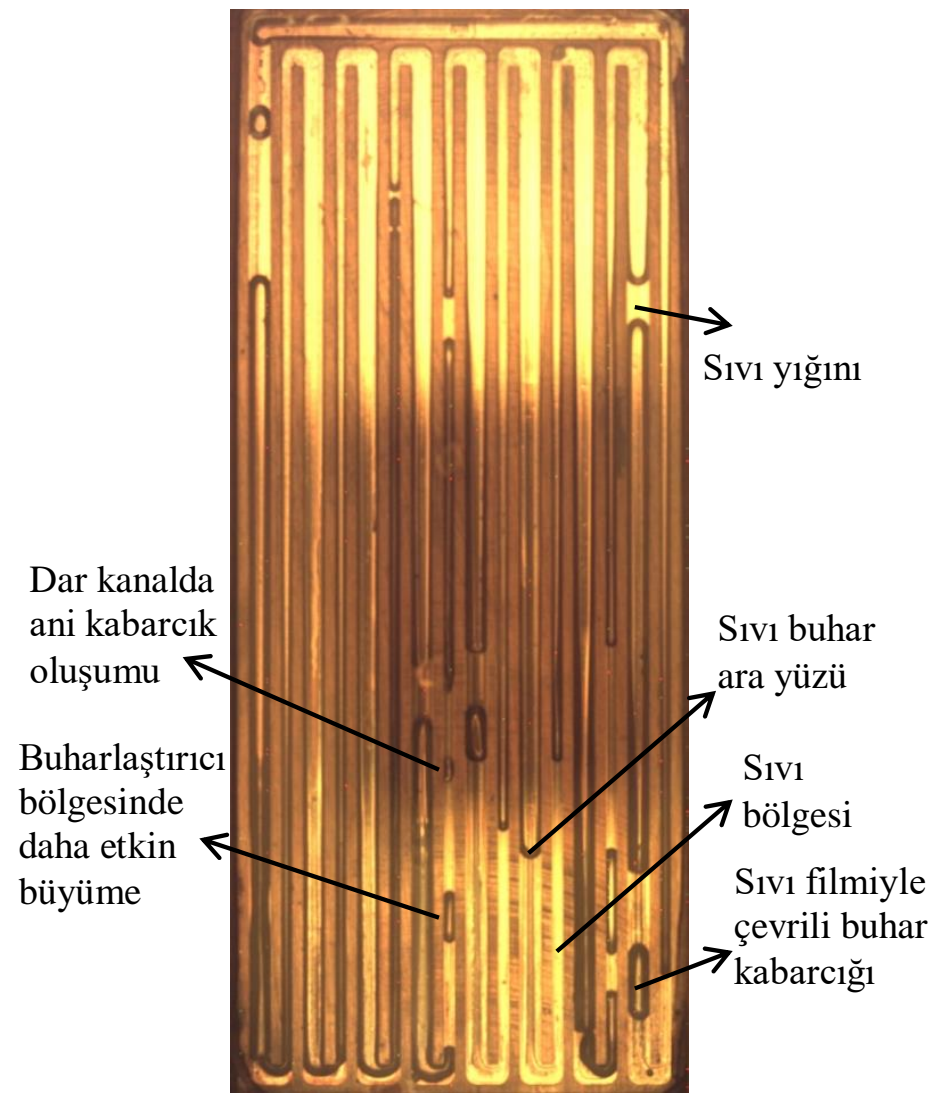

(a)

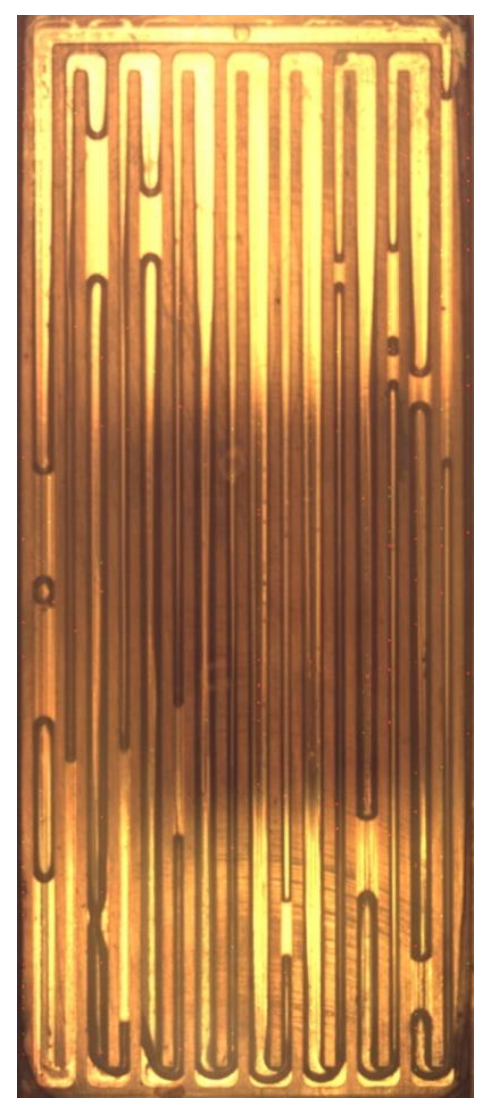

(b)

Şekil 4. $I A=90^{\circ}$ ve $I G=25 W$ koşullart için akış görüntüleri: (a) $\mathrm{E}: \mathrm{M}=1: 2$ ve (b) $\mathrm{E}: \mathrm{M}=2: 1$ 


\section{B. EĞìM AÇISI ETKİsi}

Eğim açısı etkisini gösterecek formda düzenlenen grafikler Şekil 5 'te sunulmuştur. Çalışma kapsamında, $0^{\circ}, 45^{\circ}$ ve $90^{\circ}$ olmak üzere üç farklı eğim açısında çalışılmıştır. Burada, en kritik açı değerleri, yatay $\left(0^{\circ}\right)$ ve düşey konumu $\left(90^{\circ}\right.$, alttan 1sitma) temsil eden PHP yerleşimleridir.

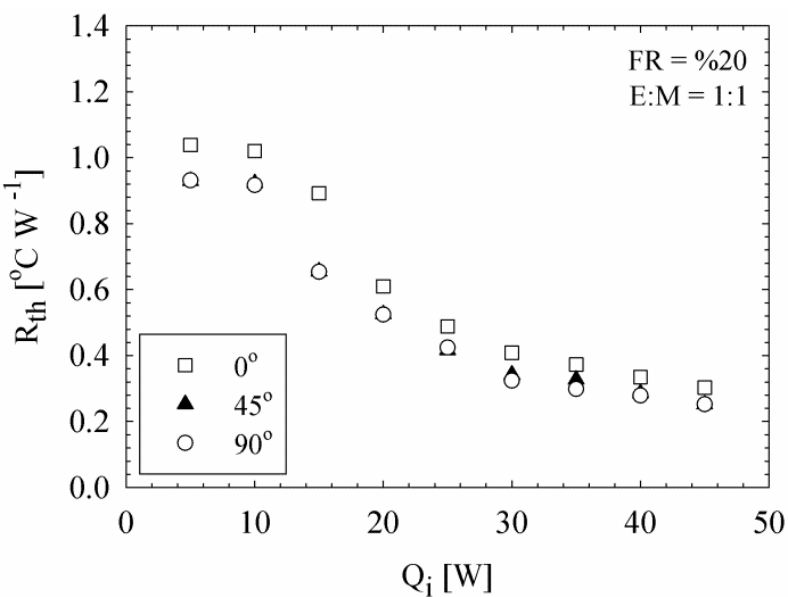

(a)

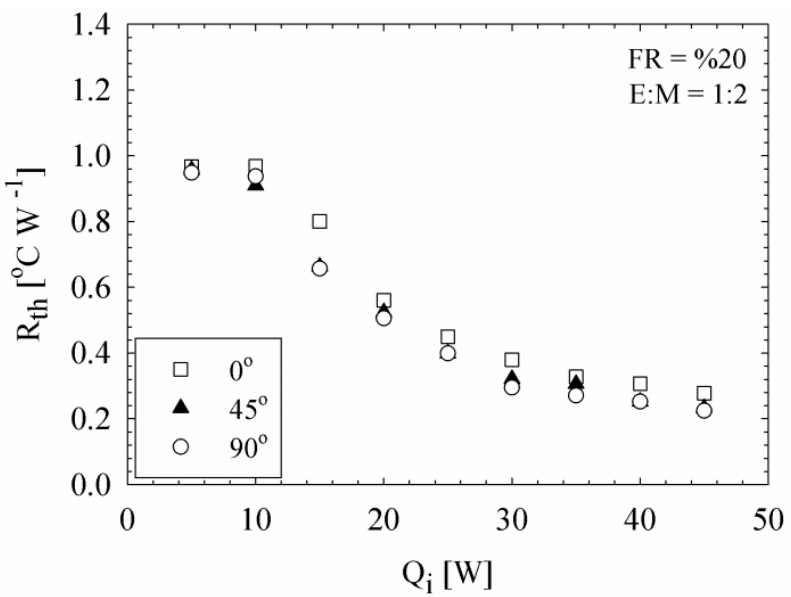

(c)

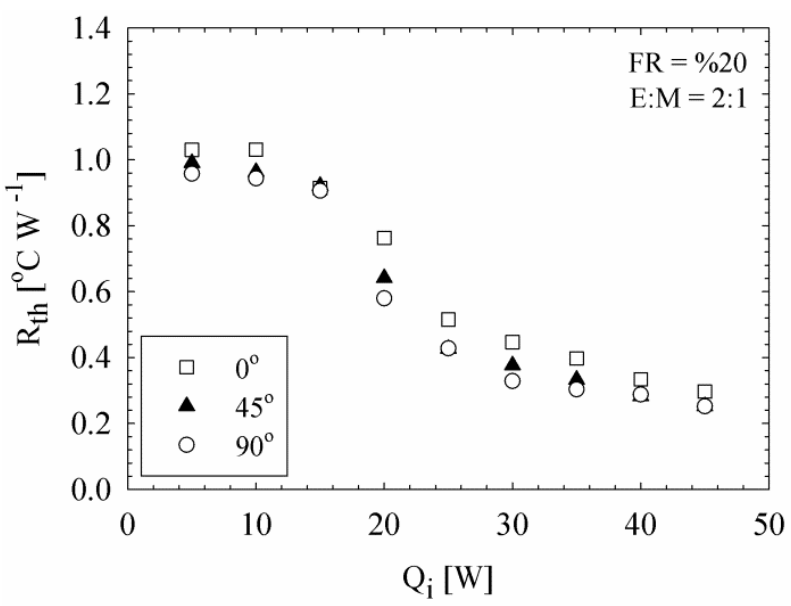

(e)

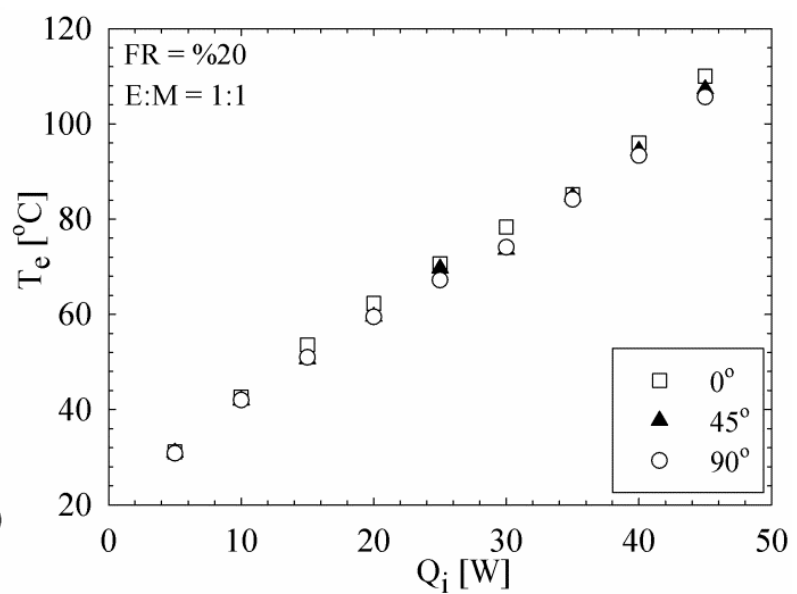

(b)

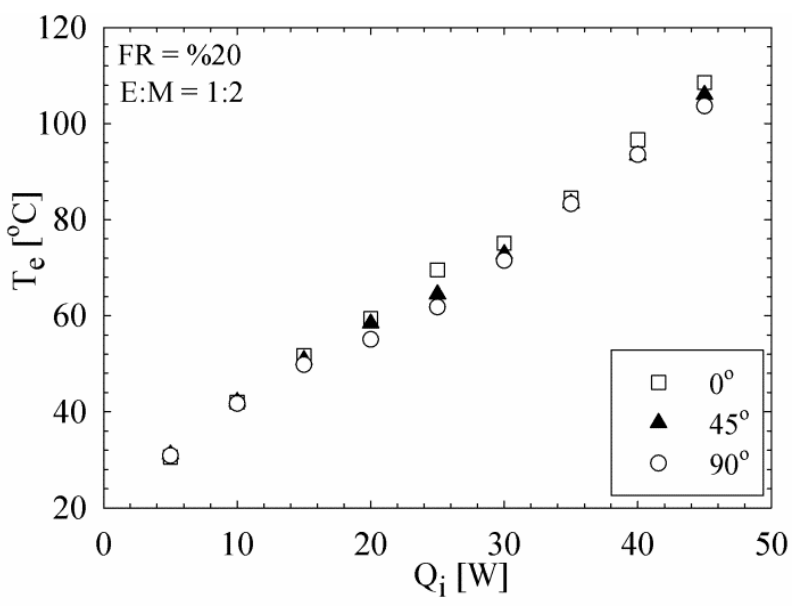

(d)

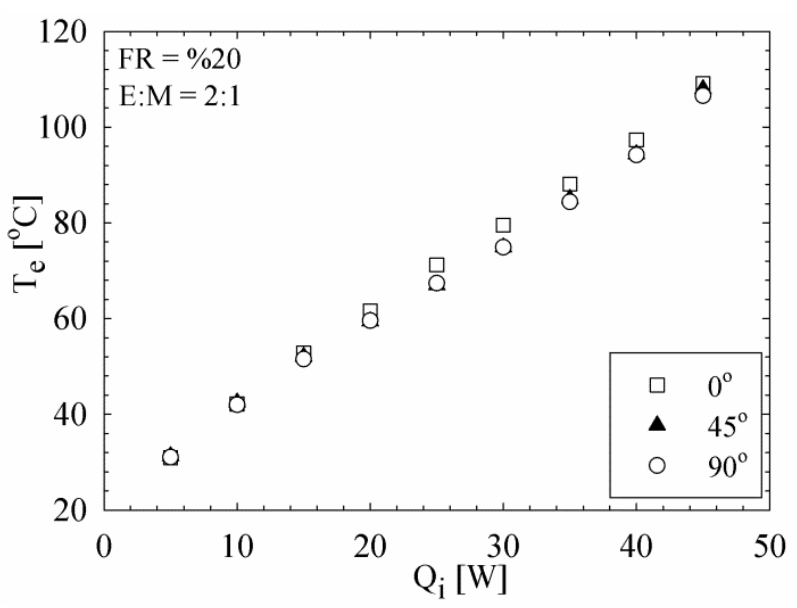

$(f)$

Şekil 5. PHP'nin ısıl direnç ve buharlaştırıcı sıcaklı̆̆ının farklı eğim açıları için ısıl güç ile değişimi: (a) $R_{\text {th }}$ $E: M=1: 1,(b) T_{e}, E: M=1: 1,(\boldsymbol{c}) R_{t h}, E: M=1: 2,(d) T_{e}, E: M=1: 2$, (e) $R_{t h}, E: M=2: 1$ ve $(f) T_{e}, E: M=2: 1$ 
Düşey konum, fiziksel olarak, yer çekimi kuvveti desteğinin maksimum düzeyde olduğu; yatay konum ise yer çekimi desteğinin olmadığı koşulu tanımlamaktadır. Yer çekimi kuvveti ise, üniform kanallı atımlı 1sı borularında, iç basınç pertürbasyonların en önemli kaynaklarından biri olup; giriş bölümünde de özetlendiği üzere, bu kuvvetin eksikliği, az döngü sayısına sahip atımlı 1sı borularının yatay konumda çalışamamasının birincil sebebidir. Buna karşın, Şekil 5'te verilen isıl direnç-1sıl güç değişim grafikleri incelendiği zaman, tüm karışım oranları için, çalışma kapsamında kullanılan ısı borusunun, tüm eğim açısı değerlerinde başarılı bir şekilde çalışabildiği görülmektedir.

Isı borusunun, tüm karışım oranları için, neredeyse açıdan bağımsız şekilde çalışabilmesinin birincil sebebi, kullanılan ısı borusunun geometrisi ve bu geometriye bağlı olarak ortaya çıkan farklı sürücü kuvvetlerdir. Isı borusu, farklı kesite sahip paralel kanalların ardışık olarak sıralandığ değişken kesitli bir yapıdadır. Paralel kanalların farklı kesitlerde olması; kılcallık kuvveti, kayma kuvveti ve buharlaşma momentum kuvvetinin dengelenmemiş formlarının oluşumuna yol açar ve basınç çalkantılarını destekler. Böylece, az döngü sayısına sahip atımlı 1sı borusu, yer çekimi desteği olmadan da çalışabilmektedir.

Yukarıda belirtildiği üzere, ikili karışımla yüklenen PHP, tüm karışım oranlarında çalışabilmektedir; ancak, Şekil 5 'ten de görüldüğü üzere, açısal değişime bağımlılık karışım oranıyla da ilişkilidir. Açısal bağımsızlık açısından en iyi performans da, 1sıl performansta olduğu gibi, E:M=1:2 için elde edilmiş̧ir. Sonuç olarak, hacimsel karışım oranı veya bir başka ifade ile ikili karışım içerisinde yer alan akışkanların oranı değiştikçe, açıdan bağımsız çalışabilme performansı iyileştirilebilir.

\section{IV.SONUC}

Bu deneysel çalışmada, düşük bir dolum oranında ikili karışımlarla yüklü, üniform olmayan kanal profiline sahip düz plakalı kapalı döngülü atımlı bir 1sı borusunun 1sıl performansı ve akış davranış1 incelenmiştir. Bir önceki bölümde detaylı olarak yapılan değerlendirmeler doğrultusunda, önemli sonuçlar, aşağıda maddeler halinde özetlenmiştir.

- Tüm çalışma koşullarında, genel bir davranış olarak, belli bir ısıl güç değerine kadar yatay eğilim gösteren 1sıl dirençte, ani bir azalma meydana gelmekte ve devamında 1sıl direnç değerleri artan 1sıl güç ile azalmaktadır. Isıl dirençte görülen ani azalma, PHP'nin çalışmaya başladığının göstergesidir.

- Akışın artan ısıl güç sonucu hızlanmasına ek olarak, akış desenleri ve kabarcık dinamiği de 1sıl direncin azalmasında ve ısıl performansın artmasında önemli rol oynamaktadır.

- Karışım içindeki metanol oranının artması ile 1sıl performansın arttığı görülmektedir. Tüm açısal yerleşimlerde, genel karakter olarak, en düşük isıl direnç ve buharlaştırıcı sıcaklığ değerleri $\mathrm{E}: \mathrm{M}=1: 2$ için elde edilmiştir. Buna karşın, en yüksek ısıl direnç ve buharlaştırıcı sıcaklığ 1 değerleri ise $E: M=2: 1$ karışımı kullanıldığında elde edilmiştir. Ayrıca $E: M=1: 2$ ve $\mathrm{E}: \mathrm{M}=1: 1$ karışımları ile yüklenen $1 \mathrm{~s} 1$ borusu $15 \mathrm{~W}$ 1sıl yük altında çalışmaya başlarken; E:M=2:1 akışkanı ile yüklü 1sı borusu 20W'ta çalışmaya başlamaktadır. Çalışma kapsamındaki tüm veri tabanı üzerinden değerlendirildiğinde, E:M=1:2'nin 1sıl direnci, E:M=2:1'e kıyasla yaklaşık \%39'a kadar daha düşük değer alabilmektedir.

- Isıl direnç-1sıl güç değişim grafikleri incelendiği zaman, tüm karışım oranları için, çalışma kapsamında kullanılan 1Sı borusunun, tüm eğim açısı değerlerinde başarılı bir şekilde çalışabildiği görülmektedir.

- Isı borusu, farklı kesite sahip paralel kanalların ardışık olarak sıralandığı değişken kesitli bir yapıdadır. Paralel kanalların farklı kesitlerde olması; kılcallık kuvveti, kayma kuvveti ve buharlaşma momentum kuvvetinin dengelenmemiş formlarının oluşumuna yol açar ve basınç çalkantılarını destekler. Böylece, az döngü sayısına sahip atımlı 1sı borusu, yer çekimi desteği olmadan da çalışabilmiştir.

- İkili karışımla yüklenen PHP, tüm karışım oranlarında çalışabilmektedir; ancak, açısal değişime bağımlılık, karışım oranıyla da ilişkilidir. Açısal bağımsızlık bakımından, en iyi 
performans E:M=1:2 için elde edilmiştir. Sonuç olarak, hacimsel karışım oranı değiştirilerek, açıdan bağımsız çalışabilme performansı iyileştirilebilmektedir.

- Çalışma kapsamında ortaya çıkan önemli sonuçlardan birisi de \%20 gibi oldukça düşük bir dolum oranında, atımlı is borusunun, açıdan bağımsız olarak ve yüksek performansla çalışabildiğinin gösterilmiş olmasıdır.

TEŞEKKÜR: $\mathrm{Bu}$ çalışma Türkiye Bilimsel ve Teknolojik Araştırma Kurumu (TÜBİTAK) tarafindan desteklenmiştir (Proje no: 217M341).

\section{KAYNAKLAR}

[1] H. Akachi, "Structure of a heat pipe," U.S. Patent 4921 041, May, 1, 1990.

[2] M. Mameli, L. Araneo, S. Filippeschi, L. Marelli, R. Testa, and M. Marengo, "Thermal response of a closed loop pulsating heat pipe under a varying gravity force," International Journal of Thermal Science, vol. 80, pp. 11-22, 2014.

[3] V. Ayel, L. Araneo, A. Scalambra, M. Mameli, C. Romestant, A. Piteau, M. Marengo, S. Filippeschi, and Y. Bertin, "Experimental study of a closed loop flat plate pulsating heat pipe under a varying gravity force," International Journal of Thermal Science, vol. 96, pp. 23-34, 2015.

[4] L. Lv, J. Li, and G. Zhou, "A robust pulsating heat pipe cooler for integrated high power LED chips," Heat Mass Transfer, vol. 53, pp. 3305-3313, 2017.

[5] M. Cheng, and J. Li, "Nanofluid-based pulsating heat pipe for thermal management of lithium-ion batteries for electric vehicles," Journal of Energy Storage, vol. 32, 2020, Art. no. 101715.

[6] P. Khalilmmoghadam, A. Rajabi-Ghahnavieh, and M. B. Shafii, "A novel energy storage system for latent heat recovery in solar still using phase change material and pulsating heat pipe," Renewable Energy, vol. 163, pp. 2115-2127, 2021.

[7] P. Charoensawan, S. Khandekar, M. Groll, and P. Terdtoon, "Closed loop pulsating heat pipes Part A: parametric experimental investigations," Applied Thermal Engineering, vol. 23, pp. 20092020, 2003.

[8] S. Khandekar, N. Dollinger, and M. Groll, "Understanding operational regimes of closed loop pulsating heat pipes: An experimental study," Applied Thermal Engineering, vol. 23, pp. 707-719, 2003.

[9] S. Jun, and S. J. Kim, "Comparison of the thermal performance and flow characteristics between closed-loop and closed-end micro pulsating heat pipes," International Journal of Heat and Mass Transfer, vol. 95, pp. 890-901, 2016.

[10] G. Spinato, N. Borhani, and J. R. Thome, "Operational regimes in a closed loop pulsating heat pipe,” International Journal of Thermal Sciences, vol. 102, pp. 78-88, 2016.

[11] K. H. Chien, Y. T. Lin, Y. R. Chen, K. S. Yang, and C. C. Wang, "A novel design of pulsating heat pipe with fewer turns applicable to all orientations," International Journal of Heat and Mass Transfer, vol. 55, pp. 5722-5728, 2012.

[12] G. H. Kwon, and S. J. Kim, "Operational characteristic of pulsating heat pipes with a dualdiameter tube," International Journal of Heat and Mass Transfer, vol. 75, pp. 184-195, 2014. 
[13] G. H. Kwon, and S. J. Kim, "Experimental investigation on the thermal performance of a micro pulsating heat pipe with a dual-diameter channel," International Journal of Heat and Mass Transfer, vol. 89, pp. 817-828, 2015.

[14] Z. Wan, X. Wang, and C. Feng, "Heat transfer performances of the capillary loop pulsating heat pipes with spring-loaded check valve," Applied Thermal Engineering, vol. 197, 2020, Art. no. 114803

[15] Y. Zhu, X. Cui, H. Han, and S. Sun, "The study on the difference of the start-up and heattransfer performance of the pulsating heat pipe with water-acetone mixtures," International Journal of Heat and Mass Transfer, vol. 77, pp. 834-842, 2014.

[16] X. Han, X. Cui, Y. Zhu, T. Xu, Y. Sui, and S. Sun, "Experimental study on a closed-loop pulsating heat pipe (CLHP) charged with water-based binary zeotropes and the corresponding pure fluids," Energy, vol. 109, pp. 724-736, 2016.

[17] X. Cui, Z. Qiu, J. Weng, and Z. Li, “ Heat transfer performance of closed loop pulsating heat pipes with methanol-based binary mixtures," Experimental Thermal Fluid Science, vol. 76, pp. 253$263,2016$.

[18] W. Wang, X. Cui, and Y. Zhu, "Heat transfer performance of a pulsating heat pipe charged with acetone-based mixtures," Heat Mass Transfer, vol. 53, pp. 1983-1994, 2017.

[19] R. Xu, C. Zhang, H. Chen, Q. Wu, and R. Wang, "Heat transfer performance of pulsating heat pipe with zeotropic immiscible binary mixtures," International Journal of Heat and Mass Transfer, vol. 137, pp. 31-41, 2019.

[20] B. Markal, and R. Varol, "Thermal investigation and flow pattern analysis of a closed-loop pulsating heat pipe with binary mixtures," Journal of the Brazilian Society of Mechanical Science and Engineering, vol. 42, 2020, Art. no. 549.

[21] B. Markal, and R. Varol, "Experimental investigation and force analysis of flat-plate type pulsating heat pipes having ternary mixtures," International Communications in Heat and Mass Transfer, vol. 121, 2021, Art. no. 105084.

[22] B. Markal, and K. Aksoy, "The combined effects of filling ratio and inclination angle on thermal performance of a closed loop pulsating heat pipe," Heat and Mass Transfer, 2020. Available: https://doi.org/10.1007/s00231-020-02988-6

[23] K. S. Yang, Y. C. Cheng, M. C. Liu, and J. C. Shyu, "Micro pulsating heat pipes with alternate microchannel widths," Applied Thermal Engineering, vol. 83, pp. 131-138, 2015.

[24] S. J. Kline, and F. A. McClintock, "Describing uncertainties in single-sample experiments," Mechanical Engineering, vol. 75, no. 1, pp. 3-8, 1953.

[25] H. Yang, S. Khandekar, and M. Groll, "Performance characteristics of pulsating heat pipes as integral thermal spreaders," International Journal of Thermal Sciences, vol. 48, pp. 815-824, 2009.

[26] X. Liu, X. Han, Z. Wang, G. Hao, Z. Zhang, and Y. Chen, "Application of an anti-gravity oscillating heat pipe on enhancement of waste heat recovery," Energy Conversion and Management, vol. 205, 2020 Art. no. 112404.

[27] S. Shi, X. Cui, H. Han, J. Weng, and Z. Li, "A study of the heat transfer performance of a pulsating heat pipe with ethanol-based mixtures," Applied Thermal Engineering, vol. 102, pp. 12191227, 2016. 